American Journal of Agricultural and Biological Sciences 5 (4): 477-485, 2010

ISSN 1557-4989

(C) 2010 Science Publications

\title{
New Antifungal Bacteriocin-Synthesizing Strains of Lactococcus lactis ssp. lactis as the Perspective Biopreservatives for Protection of Raw Smoked Sausages
}

\author{
${ }^{1}$ L.G. Stoyanova, ${ }^{1}$ E.A. Ustyugova, ${ }^{1}$ T.D. Sultimova, ${ }^{1}$ E.N. Bilanenko, \\ ${ }^{2}$ G.B Fedorova, ${ }^{2}$ G.S Khatrukha and ${ }^{1}$ A.I. Netrusov \\ ${ }^{1}$ Department of Microbiology, Faculty of Biological, \\ M.V. Lomonosov Moscow State University Lenin's Hills, Moscow, Russia, 119992 \\ Laboratory of Chemical Research of Antibiotics, G.F. Gauze Institute of New Antibiotics RAMS, \\ Bolshaya Pirogovskaya, 11, Moscow, Russia, 119021
}

\begin{abstract}
Problem statement: Screening for the effective bacteriocin-synthesizing strains of Lactococcus lactis as the perspective biopreservatives was performed. We used a raw milk and dairy products from different climatic regions as well as from powerful drinks of mixed lactic acid and alcoholic fermentation: kurunga, kumiss and Iranian "Dough", that were widely used by local population to prevent diseases. Approach: The special interest was paid to isolates of lactococci with antagonistic activity. According to their morphological, cultural, physiological, biochemical properties and sequence of $16 S$ rRNA gene they were identified as Lactococcus lactis ssp. lactis. Only nine from the selected 94 strains expressed a broad spectrum of activity against Gram-positive and Gramnegative bacteria including pathogens (Staphylococcus aureus, Escherichia coli, Pseudomonas aeruginosa, Proteus vulgaris, Salmonella gallinarum), moulds (Aspergillus, Fusarium, Penicillium genera), as well as yeasts (Rhodotorula, Candida). Results: It reveals the unique biological properties for isolated natural strains of Lactococcus lactis species. Most effective new bacteriocin-synthesizing strains 194 and K-205 were isolated from raw cow milk and kurunga from Buryatia. These strains had high antibiotic activity up to 3600 and $2700 \mathrm{IU} \mathrm{mL}^{-1}$ as compared to nisin and up to 2500-1700 IU $\mathrm{mL}^{-1}$ as compared to fungicidal antibiotic nistatin. In our experiments we used raw smoked sausages that were infected with fungi. The identification of this infection showed the presence of Eurotium repens de Bary on the sausages. Treatment of the raw smoked sausages with cultural broth of L.lactis ssp. lactis 194 and K-205 inhibited growth of these microorganisms. After treatment the sausages had longer shelf-life and was in accordance with basal production data (Russian State Standard Specification 16131-86). Conclusion: The results of this study indicated that the treatment with lactococci strains can prevent a contamination of raw smoked sausages by potential food-borne pathogens.
\end{abstract}

Key words: Anti-fungal bacteriocins, biopreservatives, lactococci, smoked sausages

\section{INTRODUCTION}

Bacterial and fungal spoilage of foodstuffs is a common and global-wide phenomenon. In additional to economic losses, the potential production by toxinogenic bacteria and fungal toxins is a particular health concern. It is true that the growth of toxinogenic bacteria and moulds can now be prevented in almost all foodstuffs by means of a large number of chemical additives or by physical treatments (heat, ultra-violet rays ets). Chemical preservatives and antibiotics that increase shelf-life of foodstuffs cause concern. In last year preservative «Delvocide» (Gist-Brocade Co., The Netherlands) made on basis of fungicidal antibiotic Natamicin is used in sausage production (Gost 1613186). The reasons for these are to be found in the allergenic potential of many additives. Besides, the possibility cannot be excluded that the preservatives are metabolized in vivo to produce a toxic substances. One example of this is the formation of carcinogenic nitrosamines from nitrite which is used for meat storage.

In turn lactic acid bacteria, due to their completely harmless to health and antagonistic activity against a large variety of microorganisms, are widely used as

Corresponding Author: L.G. Stoyanova, Department of Microbiology, Faculty of Biology,

M.V. Lomonosov Moscow State University, Lenin's Hills, Moscow, Russia, 119992 
biopreservatives. The traditional use of dairy lactococci in various food fermentations, their "Generally Recognized As Safe" (GRAS) status, non-pathogenicity and presence of antagonistic properties provide the basis for its safely use for food protection as a food biopreservatives. Antagonistic activity of lactococci provided by synthesis of organic acids (acetic and lactic acids), diacetyl, bacteriocins and also low-molecular substances with antifungal activity (Roy et al., 1996; Lowe et al., 2004).

Bacteriocins are protein substances which exhibit antibacterial activity against closely related species (Jack et al., 1995). Bacteriocins can inhibit very restricted spectrum of bacteria, mostly limited to Grampositive bacteria. Different bacteriocins differ from each other by chemical structure and antagonistic activity. Lactococcus lactis produces such bacteriocins as lacticin 481, lacticin 3147, several forms of nisin and lactococcins (Morgan et al., 2005; Fujita et al., 2007). Nisin is the most studied bacteriocin which is allowed for application as food preservative by (European Parliament and Council, 1997) (code E234). Since 1997 nisin has status «GRAS» and it has been recognized as absolutely safe. Additions of bacteriocins decrease sterilization time and increase shelf-life of foodstuff (Drider et al., 2006). As a result power inputs decrease by $15-25 \%$ as well as increase of safe food value. Nisin is the low-molecular mass protein so it is easy to apart it into amino acids during digestion and do not influence microbiota of gastrointestinal tract (Nete et al., 2006). Several types of nisin (A, B, C, D, E, Z, R, Q) differ from each other by some physicochemical properties, amino acid composition and antimicrobial activity spectrum. All these bacteriocins are produced by different strains of Lactococcus lactis ssp. lactis (Jensen et al., 2001, Zendo et al., 2003; Yildirim et al., 2004). But use of bacteriocins as biopreservatives is problematic because bacteriocins, including nisin, frequently lack stability in the foodstuffs and strains resistant to nisin have occur (Cutter and Siragusa, 1994; Mantovani et al., 2001; Drider et al., 2006; Galvez et al., 2007). So now nisin is considered as not effective for storage of meat and other foodstuffs. At present, the ways of targeted synthesis of antibiotic substances by lactococci are studied in order to obtain new ones with more valuable properties and safe for use as biopreservatives (Drider et al., 2006; Stoyanova et al., 2006).

The aim of this study was to isolate and identify the new antifungal lactococci and evaluate their potential use for preventing fungal spoilage.

\section{MATERIALS AND METHODS}

Isolation of lactococci strains: The probes from raw milk and dairy products from different climatic regions and also powerful drinks of mixed lactic acid and alcoholic fermentation: kurunga, kumiss and Iranian "Dough" were taken to isolate the cultures. Raw cow's milk probes were obtained from the milk farm of the Timiryazev Agricultural University (Moscow, Russia), milk-processing plants of Klin (Moscow region, Russia) and Ulan-Ude (Buryatia, Russia) and also were used in this work. Mare's milk and kumiss were obtained from Ufa (Bashkiria, Russia), kurunga - from Ulan-Ude, drink "Dough" - from Teheran (Iran). The tubes with milk probes were incubated during $17 \mathrm{~h}$ for self-fermentation at $28^{\circ} \mathrm{C}$. In each tubes with sterile skim milk 0.5 vol. \% of probe was added. Then bacteria from the tubes with dense milk clot underwent to several passages in sterile milk and cultivated for 10-17 h. To isolate a homolactic lactococci the cultures were transferred on the agar milk hydrolysate with bromocresol purple as indicator. Individual acidforming colonies from the surface of the agar medium were transferred in Petri dish with a lawn of test culture Bacillus coagulans using a sterile replicator and, in parallel, to the MRS medium without the test culture. The clones that formed largest growth inhibition zones of the test microorganism were selected. To obtain a lawn of the test culture, a suspension of 24-h-old culture of the thermophylic spore-forming bacterium $B$. coagulans 429 , preliminary grown at $55^{\circ} \mathrm{C}$ on the solid organic medium (10.0 g/l glucose, $5.0 \mathrm{~g} / \mathrm{l}$ peptone, 5.0 $\mathrm{g} / \mathrm{l} \mathrm{NaCl}, 20.0 \mathrm{~g} / \mathrm{l}$ agar with an addition of Hottinger's broth at a concentration of $0.028 \%$ of amine nitrogen; $\mathrm{pH}$ 7.0) was transferred in Petri dishes.

The morphology of the isolated strains was examined with an MBI-15 microscope equipped with a KF-4 phase contrast condenser (LOMO, MicMed, St.Petersburgh, Russia). Cultural properties of the isolated strains were examined by classical microbiological methods for identification and determination of the culture (Hoelt et al., 1994).

Subculture $\left(\mathrm{OD}_{540} 0.14-0.19\right)$ was inoculated in an amount of $5 \%(\mathrm{v} / \mathrm{v})$ into the base fermentation medium, which contained $20 \mathrm{~g} \mathrm{~L}^{-1} \mathrm{KH}_{2} \mathrm{PO}_{4}, 10 \mathrm{~g} \mathrm{~L}^{-1}$ glucose, yeast autolysate $\left(0.035 \%\right.$ ammonium nitrogen), $1 \mathrm{~g} \mathrm{~L}^{-1}$ $\mathrm{NaCl}$ and $0.2 \mathrm{~g} \mathrm{~L}^{-1} \mathrm{MgSO}_{4}(\mathrm{pH}$ 6.8-7.0; $\mathrm{pH}$ was adjusted by $10 \% \mathrm{NaOH}$ ).

To study the effect of carbon source on biomass growth, $\mathrm{pH}$ kinetics and the level of antibiotic activity, a series of carbohydrates was used: D-arabinose, Dxylose, D-ribose, D-glucose, L-rhamnose, D-maltose, D-sucrose, D-mannose, D-lactose, D-galactose, raffinose, D-fructose, D-sorbitol, dulcitol, mannitol, dextrin, glycerol and starch. Each carbohydrate was added to the base fermentation medium in the amount of $1.0 \%$ each (Hoelt et al., 1994; Stoyanova and Levina, 2006). 
The effect of amino acids on bacterial growth and synthesis of antibiotic substances was studied using DL-valine, DL-threonine, DL-leucine, L-serine, Llysine, DL-cystine, L-glutamate, L-aspartate, Lisoleucine, L-methionine and L-cysteine. Each amino acid was added into the fermentation medium in the amount of $0.01 \%$ (Stoyanova et al., 2008).

The antibiotic activity of lactic acid bacteria was determined by agar diffusion method using Bacillus coagulans as test microorganism (Stoyanova et al., 2006).

Spectrum of antimicrobial action evaluation: The spectrum of antibiotic activity of the strains was studied by culturing strains under stationary conditions in the basic fermentation medium for $17-20 \mathrm{~h}$. The microorganisms used in these experiments were from the Culture Collection of the Microbiology Department of Moscow State University: six strains of Grampositive bacteria: Micrococcus luteus 128, Bacillus mycoides 32, B. subtilis 2, B. coagulans 429, B. cereus 112 and Staphylococcus aureus 144; five strains of Gram-negative bacteria: Alcaligenes faecalis 82, Escherichia coli 52, Proteus vulgaris 206, Pseudomonas aeruginosa 54, Salmonella gallinarum; five strains of fungi: Fusarium oxysporum 61, Penicillium chrysogenum 37, Aspergillus niger 369, included two yeast strains: Candida albicans 217 and Rhodotorula aurantiaca 226.

The bacilli were grown on an organic medium containing ( $\left.\mathbf{g ~ L}^{-1}\right)$ : glucose (10.0), peptone (5.0), $\mathrm{NaCl}$ (5.0) and agar (25.0); the medium was supplemented by Hottinger's broth $(0.025 \%$ amine nitrogen) and had a $\mathrm{pH}$ of 7.0. The yeasts were grown on a wort $\left(6-8^{\circ} \mathrm{B}\right)$ medium supplemented with $2.5 \%$ agar ( $\mathrm{pH} 6.8$ ). The medium for the fungi was similar (wort $3-4^{\circ} \mathrm{B}$ with $2.0 \%$ agar; $\mathrm{pH}$ 6.0). In the case of bacilli, staphylococci, $E$. coli and micrococci the temperature of cultivation was $37^{\circ} \mathrm{C} ; B$. coagulans $55^{\circ} \mathrm{C}$ and yeasts and fungi- $28^{\circ} \mathrm{C}$. Petri dishes were inoculated with 1 day cultures of test microorganisms $(0.1 \mathrm{~mL}$ cell suspension in physiological saline per dish; the concentrations were adjusted to $10^{9} \mathrm{CFU} \mathrm{mL}$ using a bacterial turbidity standard).

The bacteriocin-synthesizing activity was assessed as nisin production (judged by the suppression of growth of the indicator culture $B$. coagulans, a thermophilic spore-forming acid-fast bacterium). A 1-day culture was introduced into the agar medium as a suspension with a density of $10^{9}$ cell $\mathrm{mL}^{-1}$. Quantitative determination of the antibiotic activity was performed by measuring the zones of growth suppression with subsequent calculation involving a calibration plot for standard nisin solutions. Solutions of the preparation Nisaplin (Applin and Barrett, United Kingdom, $1000 \mathrm{IU} \mathrm{mg}^{-1}$ ) and Nistatin (Sigma, Germany, 4670 units $\mathrm{mg}^{-1}$ ) used as the standards (Stoyanova et al., 2006).

Isolation of antibiotic substances: Methods for isolation and purification of antibiotic substances have been developed to obtain individual components of antibiotic complex as chromatographically pure preparations. In order to separate the antibiotic substances into fractions and obtain chromatographically pure components, the aqueous concentrate was extracted with a water-immissible organic solvent, after which the extracts were pooled and the solvent was evaporated on a rotary evaporator to yield an oily residue. This oily residue was precipitated with methanol. The precipitate was separated via glass filter, dried under vacuum and then kept in a desiccator (Stoyanova et al., 2007).

Chromatographic analysis: Fractions of the antibiotic substances were separated by TLC on Silufol (Czech Republic) or DC-Alufolien Kieselgel 60 (Merck, Germany) plates, using the developing system methanol-water (96:4). Preparative chromatography (to obtain individual components of the fractions) was performed under the same conditions.

Electrophoresis was performed on a Filtrak F-14 paper (Germany), using a V-shaped Durum instrument and two electrolytes: E1, pH 2.4 (2 N acetic acid; 550 $\mathrm{V}, 2 \mathrm{~h})$ and $\mathrm{E} 2, \mathrm{pH} 1.1$ (28:20:52 mixture of formic acid, acetic acid and water; $270 \mathrm{~V}, 2-3 \mathrm{~h}$ ).

Bioautography was performed with $B$. coagulans 429, B. subtilis ATCC 6633 (RIA 445) and Aspergillus niger 369 were served as test microorganisms.

The fungicidal activity was tested with indicator culture Eurotium repens. Solutions of the fungicidal antibiotic nistatin (activity $4670 \mathrm{IU} \mathrm{mg}^{-1}$ were served as the standards.

Testing the lactococci strains as preservatives: Experiments to show a perspectivity of the strains of $L$. lactis ssp. lactis 194 or K-205 as biopreservatives were performed. Two samples of raw smoked sausages, prepared accordingly with Russian State Standard (Gost 16131-86,) and became infected with moulds, were used as objects of investigation. Samples from the surface of raw smoked sausages with visible spots of spoilage were collected and placed on the surface of 
two different media: Chapek agar (CA, pH 5.5), containing $\left(\mathrm{g} \mathrm{L}^{-1}\right)$ : sucrose-30.0, $\mathrm{NaNO}_{3}-1.0, \mathrm{KH}_{2} \mathrm{PO}_{4}$ $1.0, \mathrm{MgSO}_{4} \times 7 \mathrm{H}_{2} \mathrm{O}-0.5, \mathrm{KCl}-0.5, \mathrm{FeSO}_{4}-0.01$, agar15.0; and malt agar (MA, $\mathrm{pH} 6.5$ ) containing $3.5 \%$ of malt extract (Maltax 10 standard, Finland). Plates were incubated at $25^{\circ} \mathrm{C}$ until fungal colonies were observed. Isolated colonies were transferred periodically into plates at $25^{\circ} \mathrm{C}$ until pure cultures were obtained. Fungal colonies were identified on the basis of morphological and physiological characteristics using common guides (Klich et al., 2002).

The surfaces of all samples of infected raw smoked sausages were disinfected with $70 \%$ solution of ethanol, dried and then treated by cultural broth of strains 194 or $\mathrm{K}-205\left(\mathrm{OD}_{540} 1.2, \mathrm{pH} 4.2\right)$. The samples of raw smoked sausages without treatment of cultural broth were served as control. The control and experimental samples of raw smoked sausages were stored for 1 month at $10^{\circ} \mathrm{C}$.

In second series of experiments before syringing with sausage stuffing's and further output, the sausage casing were dipped into cultural broth of strains of L. lactis ssp. lactis 194 or $\mathrm{K}-205\left(\mathrm{OD}_{540} 1.2, \mathrm{pH} 4.2\right)$ and exposed there for 10 and $20 \mathrm{~min}$. The technological and microbiological indexes of the samples of raw smoked sausages were studied accordingly to Russian State Standard (Gost 16131-86).

The experiments were comprised in three series of triplicate measurements each. The results were processed statistically with program OriginPro v.8.1 for Windows (OriginLab, Data Analysis Graphing Software, USA), Statistica for Windows, v.5.0 (StatSoft Inc., USA).

\section{RESULTS}

520 lactococcal strains were isolated from raw milk probes and dairy products and also from powerful drinks: kurunga, kumiss and Iranian "Dough". Overall, 155 colonies of mesophylic acid-producing bacteria were selected. Overall, 94 isolated colonies inhibited the growth of test-microorganism B. coagulans, twelwe of them displayed the highest activity (Table 1 ).

Strains designated as 115, 119, 119x were isolated from Timiryazev Agricultural University (Moscow, Russia) and strain 229-from the milk-processing plants of Klin (Moscow Region, Russia), IR1 and IR4-from Iranian milk products, strain 805-from mare's milk (Bashkiria, Russia) and 194, K-205-from cow milk of Ulan-Ude (Buryatia, Russia), were chosen for further study.

The morphology of the isolated strains demonstrated that the cultures were represented by cocci assembled in pairs or short chains of various lengths (four-seven cells). Strain 115, with morphology being reflecting of L. lactis ssp. cremoris, had the longest chains. All the bacteria isolated appeared to be Gram-positive. They did not differ by their cultural features from the bacteria belonging to the Lactococcus genus.

All these strains grew equally well in the liquid media with milk hydrolysate, a glucose-yeast medium and a meat-peptone broth with 2.0-4.0\% NaCl. Bacterial growth was indicated by an increasing of turbidity of the cultures $\left(0.24-1.56, \mathrm{OD}_{540}\right)$ and the decrease $\mathrm{pH}$ from 6.8-4.1. Growth was absent in the meat-peptone broth containing $6.5 \% \mathrm{NaCl}$ and at $\mathrm{pH}$ 9.6. The $\mathrm{pH}$ from 6.6-7.2 was optimal for the growth and development of these strains. The optimal incubation temperature was $28^{\circ} \mathrm{C}$; at $10^{\circ} \mathrm{C}$ the growth was minimal and was completely absent at $45^{\circ} \mathrm{C}$.

Table 1: Distinctive phenotypic properties of isolated antagonistic strains of Lactococcus lactis

\begin{tabular}{|c|c|c|c|c|}
\hline \multirow{2}{*}{$\begin{array}{l}\text { Number of } \\
\text { Products }\end{array}$} & \multicolumn{2}{|c|}{ Bacteriocins produced } & \multicolumn{2}{|l|}{ Strains' main } \\
\hline & strains isolated & Perspective strains & by strains, IU mL ${ }^{1}$ & distinctive properties \\
\hline Kurunga (Buryatia, Russia) & 36 & K-205 & 2500 & $\mathrm{Ala}^{+} ; \mathrm{Ara}^{+} ; \mathrm{Mtl}^{+} ; \mathrm{Dext}^{+}$ \\
\hline «Doogh» (Iran) & 25 & IR 3 & 3400 & $\mathrm{Ala}^{-} ; \mathrm{Mal}^{+} ; \mathrm{Mtl}^{+} ; \mathrm{Dext}^{+}$ \\
\hline \multicolumn{2}{|c|}{ Curdled milk (Moscow, Russia) 40} & 119 & 2700 & $\begin{array}{r}\mathrm{Pro}^{+} ; \mathrm{Ura}^{+} ; \mathrm{Ara}^{+} ; \mathrm{Mal}^{+} ; \\
\mathrm{Dext}^{+}\end{array}$ \\
\hline Cow milk (Moscow, Russia) & $\begin{array}{l}197 \\
119 x \\
115\end{array}$ & $\begin{array}{l}729 \\
3700 \mathrm{Ala}^{-} ; \mathrm{Ara}^{-} ; \mathrm{M} \\
\text { 2500Ala } ; \mathrm{Suc}^{-} ; \mathrm{M}\end{array}$ & $\begin{array}{c}300 \\
\mathrm{tl}^{-} ; \operatorname{Dext}^{-} \\
\mathrm{Cal}^{+} ; \mathrm{Dext}^{+}\end{array}$ & $\mathrm{Ala}^{-} ; \mathrm{Ura}^{+} ; \mathrm{Mal}^{+}$ \\
\hline Cow milk (Klin, Russia) & 54 & 229 & 2200 & $\mathrm{Ala}^{+} ; \mathrm{Ara}^{-} ; \mathrm{Mtl}^{-} ; \mathrm{Dext}^{+}$ \\
\hline Cow milk (Buryatia, Russia) & 78 & 194 & 3600 & $\mathrm{Ala}^{+} ; \mathrm{Ara}^{+} ; \mathrm{Xyl}^{+} ; \mathrm{Dext}^{+}$ \\
\hline \multirow[t]{3}{*}{ Cow milk (Iran) } & 35 & IR 1 & 3100 & $\mathrm{Ara}^{+} ; \mathrm{Mtl}^{-} ; \mathrm{Dext}^{+}$ \\
\hline & IR 2 & $3000 \mathrm{Asn}^{+} ; \mathrm{Mal}^{+}$ & $\mathrm{Suc}^{-}$ & \\
\hline & IR 4 & $2900 \mathrm{Ala}^{+} ; \mathrm{Mtl}^{-} ; \mathrm{I}$ & $\operatorname{Dext}^{+}$ & \\
\hline Mare's milk (Bashkiria, Russi & a) 55 & 805 & 2500 & Ala-; $\mathrm{Mal}+; \mathrm{Mtl}^{-} ; \mathrm{Suc}^{+}$ \\
\hline
\end{tabular}


Am. J. Agri. \& Biol. Sci., 5 (4): 477-485, 2010

Table 2: Antimicrobial action of isolated strains of Lactococcus lactis ssp. lactis and Nisaplin

\begin{tabular}{|c|c|c|c|c|c|c|c|c|c|c|}
\hline \multicolumn{11}{|l|}{ Strains isolated } \\
\hline $\begin{array}{c}119 \\
\text { Test organisms }\end{array}$ & $119 x$ & 729 & 229 & 194 & K-205 & IR3 & IR4 & MSU & Nisaplin & $\left(3000 \mathrm{IU} \mathrm{mL}^{-1}\right)$ \\
\hline \multicolumn{11}{|c|}{ Diameter of growth inhibition zone, $\mathrm{mm}$} \\
\hline Bacillus mycoides & 20 & 16 & 10 & 16 & 19.5 & 16.0 & 11.0 & 24 & 13 & 17 \\
\hline Bacillus subtilis & 12 & 18 & 10 & 15 & 22 & 20.0 & 11.0 & 24 & 16 & 18 \\
\hline Bacillus coagulans & 17 & 23 & 8 & 15 & 23 & 18.0 & 20.0 & 17 & 14 & 21 \\
\hline Bacillus cereus & 18.5 & 16 & 10 & 14 & 21 & 19.0 & 15.0 & 12 & 16 & 18 \\
\hline Micrococcus luteus & 21.5 & 20 & 13 & 20 & 22.5 & 16.5 & 21.5 & 19 & 19 & 25 \\
\hline Staphylococcus aureus & 16 & 12 & 0 & 16 & 20 & 17.0 & 17.0 & 16 & 12 & 15 \\
\hline Alcaligenes faecalis & 0 & 0 & 9 & 10 & 12.5 & 12.5 & 15.0 & 12 & 0 & 0 \\
\hline Escherichia coli & 0 & 0 & 11 & 0 & 15 & 14.0 & 19.0 & 12 & 0 & 0 \\
\hline Salmonella gallinarum & 0 & 0 & 0 & 0 & 16 & 14.0 & 10.5 & 12 & 0 & 0 \\
\hline Proteus vulgaris & 0 & 0 & 9 & 0 & 16.5 & 16.0 & 14.0 & 16 & 0 & 0 \\
\hline Pseudomonas aeruginosa & 0 & 0 & 0 & 0 & 16.5 & 15.5 & 12.0 & 12 & 0 & 0 \\
\hline Fusarium oxysporum & 0 & 0 & 0 & 0 & 16.5 & 12.0 & 12.0 & 10 & 0 & 0 \\
\hline Penicillium chryzogenum & 0 & 0 & 0 & 0 & 17.5 & 10.5 & 12.0 & 16 & 0 & 0 \\
\hline Aspergillus niger & 0 & 0 & 0 & 0 & 21 & 16.0 & 14.0 & 15 & 0 & 0 \\
\hline Rhodotorula aurantiaca & 0 & 0 & 0 & 0 & 19.5 & 10.0 & 13.0 & 14 & 0 & 0 \\
\hline Candida albicans & 0 & 0 & 0 & 0 & 11 & 12.0 & 10.0 & 12 & 0 & 0 \\
\hline
\end{tabular}

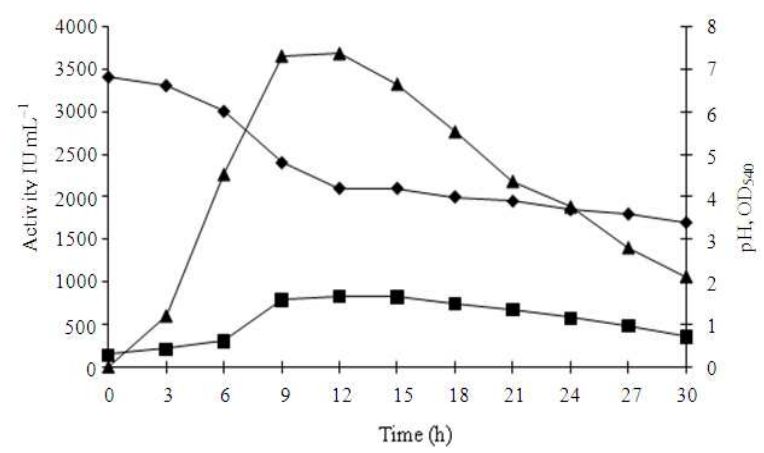

(a)

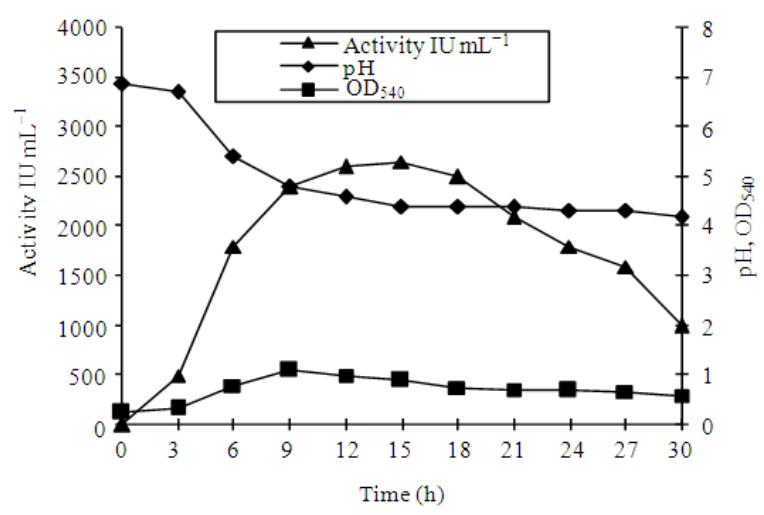

(b)

Fig. 1: Dynamic of growth and bacteriocins' synthesis by strains of Lactococcus lactis ssp. lactis194(a) and K-205 (b) in mineral medium with glucose $\left(20 \mathrm{~g} \mathrm{~L}^{-1} \mathrm{KH}_{2} \mathrm{PO}_{4}, 10 \mathrm{~g} \mathrm{~L}^{-1}\right.$ glucose, yeast autolysate)
The distinctive features of these strains with respect to the fermentation of pentoses and sugar alcohols and their requirements in growth factors, asparagine, aspartic acid, proline and uracil were determined. The strains K-205 and IR3 that have been isolated from powerful drinks had possibility to utilize mannitol (Table 1).

According to the morphological, cultural, physiological, biochemical properties and gene sequence of $16 \mathrm{~S} r R N A$ these strains were identified as Lactococcus lactis ssp. lactis.

The studies have revealed differences in antimicrobial activity between strains against different groups of microorganisms. It was demonstrated that the bacteriocins they produced varied in antagonistic activity. Some strains, isolated from milk and dairy products of Moscow region, were nisin-synthesizing (inhibit Gram-positive bacteria only). Only nine of the isolated 94 strains expressed a broad spectrum of activity against potential food pathogens: Staphylococcus aureus, Escherichia coli, Pseudomonas aeruginosa, Proteus vulgaris, Salmonella gallinarum and fungi of Aspergillus, Fusarium, Penicillium genera, as well as against Rhodotorula aurantiaca and Candida albicans (Table 2). Strains 229 and 115 produced bacteriocins that were similar to nisin A in their activity spectrum. Most effective new bacteriocinsynthesizing strains 194 and K-205 were isolated from raw cow milk and kurunga drink from Buryatia. These strains had high antibiotic activity up to 3600-2700 IU $\mathrm{mL}^{-1}$ respectively, as compared with nisin. It was important that bacteriocins produced by these strains 
Am. J. Agri. \& Biol. Sci., 5 (4): 477-485, 2010

Table 3: Physico-chemical properties of individual antibiotic substances, produced by Lactococcus lactis ssp. lactis 194

\begin{tabular}{|c|c|c|c|c|}
\hline \multicolumn{5}{|c|}{ Active components } \\
\hline Properties & 194-A & 194-B & 194-C & Nisin A \\
\hline Molecular mass, $(\mathrm{M}+\mathrm{H})+, \mathrm{m} / \mathrm{z},($ MALDI-MS) & 607.5 & 619.6 & 1995 & 3353 \\
\hline UV-VIS spectrum, $\lambda \max , \mathrm{nm}$, (solvent) & $206.8\left(\mathrm{C}_{2} \mathrm{H}_{5} \mathrm{OH}\right)$ & $224.8\left(\mathrm{C}_{2} \mathrm{H}_{5} \mathrm{OH}\right)$ & $257\left(\mathrm{C}_{2} \mathrm{H}_{5} \mathrm{OH}\right)$ & $215\left(\mathrm{H}_{2} \mathrm{O}\right)$ \\
\hline TLC $\left(\mathrm{SiO}_{2}\right), \mathrm{R}_{\mathrm{f}}$ in system: $\mathrm{MeOH}-\mathrm{H}_{2} \mathrm{O}(96: 4)$ & 0.6 & 0.42 & 0 & 0 \\
\hline $\begin{array}{l}\text { Paper electrophoresis in electrolytes } 30 \% \text { AcOH: } \\
\mathrm{pH}=2.4,550 \mathrm{~B}, 2 \mathrm{~h}, \mathrm{~cm}\end{array}$ & 0 & 0 & 7.6 & 9.5 \\
\hline Antimicrobial spectrum & Gram + and Gram- bacteria, fungi & Gram+ bacteria & Gram+ bacteria & Gram+ bacteria \\
\hline
\end{tabular}

had a wide range of activity that made them perspective for further studies.

A study of the growth dynamics of these strains in the fermentation medium with glucose and yeast autolysate demonstrated that their growth was characteristic of mesophylic lactococci (Fig. 3a). Growth in the medium containing glucose caused a $\mathrm{pH}$ lowering from 6.8-4.1. The $\mathrm{pH}$ of the medium decreased to 4.8 over $9 \mathrm{~h}$ of the growth of strain 194, which accompanied by biomass increase $\left(\mathrm{OD}_{540}\right.$, from 0.30-1.58). During cultivation antibiotic activity level increased to $3700 \mathrm{IU} \mathrm{mL} \mathrm{m}^{-1}$. The biomass accumulated gradually to $12 \mathrm{~h}$ and nisin accumulated in parallel with biomass. It was confirmed by increase of the antibiotic activity of the culture broth: after $12 \mathrm{~h}$ the $\mathrm{pH}$ dropped to 4.1 , biomass increased to 1.66 and the level of antibiotic activity elevated by 1.2 -fold (to $4500 \mathrm{IU}$ $\mathrm{mL}^{-1}$ ). After $12 \mathrm{~h}$ of incubation, the cells passed from the exponential growth phase to the stationary phase, which lasted for $3 \mathrm{~h}$. After $15 \mathrm{~h}$, a further decrease of $\mathrm{pH}$, antibiotic activity and optical density were observed due to cell lysis. The antibiotic synthesis by L.lactis ssp. lactis 194 as strain K-205 was in parallel to growth of producer with maximum of antibiotic activity at $10-12 \mathrm{~h}$ of cultivation (Fig. 1).

It has been revealed, that the both strains Lactococcus lactis ssp. lactis 194 and K-205 produced antibiotic complexes that are consisted of three components (Fig. 2). Biological and physicochemical distinctions of the bacteriocins formed by these strain were determined. Two of these components are uncharged and hydrophobic (A, B), one (C) component was positively charged. It has been elucidated that the C-component was a peptide; like nisin; accordingly to its electrophoresis migration and biological activity. Analytical HPLC, TLC, FAB-MS and FD-MS methods were carried out to determine of physico-chemical properties of new antibiotic complex components. Individual antibiotic substances differ from each other by molecular mass, $R_{\mathrm{f}}$ values and biological properties (Table 3). Component $\mathrm{C}$ had a molecular mass $1995 \mathrm{Da}$

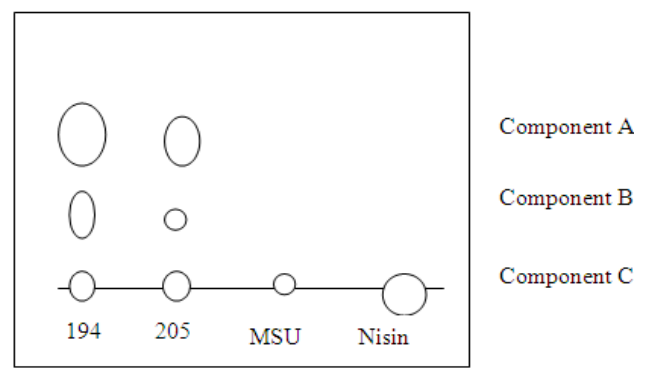

Fig. 2: TLC of antibiotic substances produced by Lactococcus lactis ssp. lactis strains 194, K-205 and MSU as compared to nisin. TLC $\left(\mathrm{SiO}_{2}\right), \mathrm{R}_{\mathrm{f}}$ in system: $\mathrm{MeOH}-\mathrm{H}_{2} \mathrm{O}$ (96:4), bio-autography, test-microorganism was $B$. coagulans

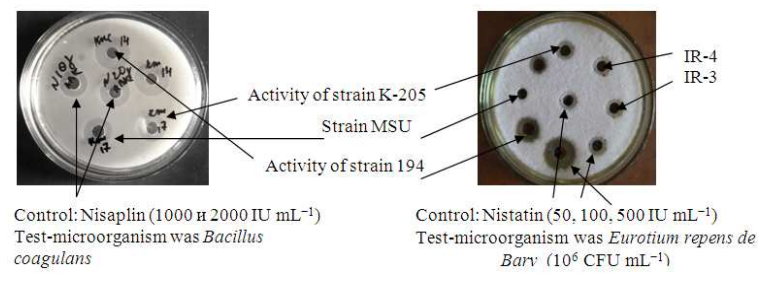

Fig. 3: Antibiotic activity of cultural broth of Lactococcus lactis ssp. lactis 194, K-205 and strain MSU against bacilli and fungi

and was a bacteriocin like nisin. Component $\mathrm{B}$ was a minor substance and its biological activity was insignificant.

Component A was hydrophobic with ketone group with double unsaturated bonds in the molecule (alkyl aromatic ketone) and had a low-molecular mass $\left(M_{r}=607.5 \mathrm{Da}\right)$. Study of antimicrobial activities of the isolated components showed that component A exhibited a broad-spectrum activity against the majority of Gram-positive, Gram-negative bacteria and fungi.

The strains 194 and K-205 had high antibiotic activity of 3600 and $2700 \mathrm{IU} \mathrm{mL} \mathrm{mL}^{-1}$ respectively in comparison with nisin and up to $2500-1700 \mathrm{IU} \mathrm{mL}^{-1}$ as compared with fungicidal antibiotic Nistatin, but nisinsynthesizing strain MSU was not effective against Eurotium repens (Fig. 3). 


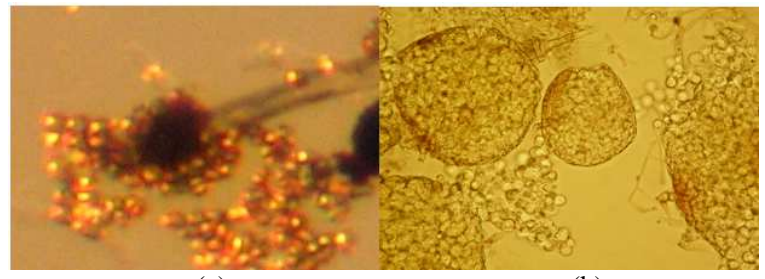

(a)

(b)

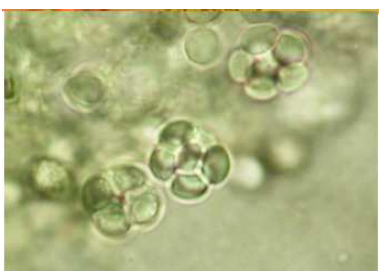

(c)

Fig. 4: Morphology of fungus Eurotium repens de Bary (anam. Aspergillus repens Samson and Gams), isolated from smocked raw sausages, as revealed by light microscopy (phase contrast, $\times 1260$ ) (a) conidia; (b) ascomata; (c) asci and ascospores

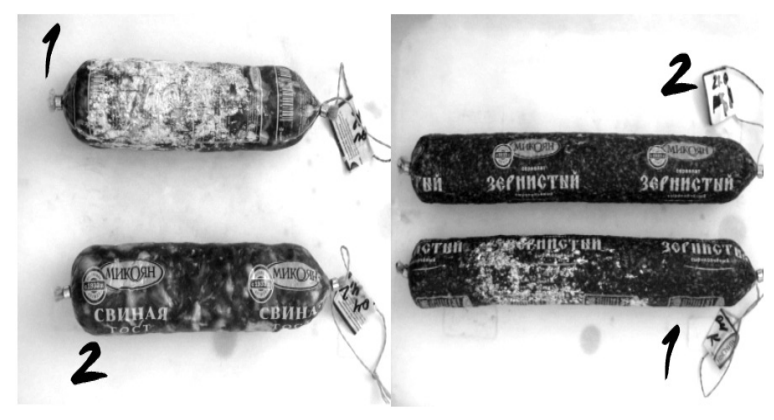

Fig. 5: Effect of treatment by Lactococcus lactis subsp. lactis 194 cultural broth on infection developing on the surface of raw smoked sausages (1control; 2-after the treatment).

In our experiment we used raw smoked sausages that were infected with mould. The identification of this infection showed the presence of Eurotium repens on the sausages (Fig. 4).

In the experiment on the sausages protection the two samples of raw smoked sausages were infected with Eurotium repens $\left(4.3 \times 10^{7}\right.$ and $3.6 \times 10^{4} \mathrm{CFU}$ $\mathrm{g}^{-1}$ ). After treatment the surfaces of two samples of infected raw smoked sausages with $70 \%$ ethanol solution, they were washed by cultural broth of strains $194\left(\mathrm{OD}_{540} 1.2, \mathrm{pH} 4.2\right)$ and then stored for one month at $10^{\circ} \mathrm{C}$. The spoilage of sample 1 decreased to $1.5 \times 10$ $\mathrm{KFU} \mathrm{g}^{-1}$ and sample 2 had no mould at all. The samples of raw smoked sausages without treatment of cultural broth which were stored for one month at $10^{\circ} \mathrm{C}$ too, were served as control. The spoilage of sample 1 was $2.3 \times 10^{6} \mathrm{CFU} \mathrm{g}^{-1}$ and sample $2-1.1 \times 10^{3} \mathrm{CFU} \mathrm{g}^{-1}$.

So it was shown that the treatment of the infected by Eurotium repens raw smoked sausages with cultural broth of strains of L. lactis subsp. lactis inhibited the spoilage. (Fig. 5).

The use of the cultural broth of L. lactis ssp. lactis 194 in the technology of production of raw smoked sausages prevented contamination of raw smoked sausages with mould. We established the longer storage of raw smoked sausages without mould developing. The integrated products corresponded to technological and microbiological indexes: food pathogens (Clostridia spp., Staphylococcus aureus, E. coli, Salmonella sp.) were absent.

\section{DISCUSSION}

Screening of effective bacteriocin-synthesizing strains of L. lactis as the perspective biopreservatives was performed. Altogether 520 lactococcal strains were isolated from raw milk probes and dairy products from various climatic regions and also from powerful drinks of mixed lactic acid and alcoholic fermentation: kurunga, kumiss and Iranian "Dough" which are widely used by local populations to prevent diseases. The lactococcal colonies were selected on the media with the indicator bromocresol purple, which changed the color of the medium from violet to yellow indicating the acidification degree. It is known that the major product of homolactic fermentation is lactic acid. Uniform growth of bacteria along the entire inoculum's length in a stab of an agar medium is characteristic of facultative anaerobes (Hoelt et al., 1994).

Physiological and biochemical features of isolated strains were studied and compared to the nisinproducing strain Lactococcus lactis ssp. lactis MSU. The strains K-205 and IR3 that have been isolated from powerful drinks of mixed lactic acid and alcoholic fermentation kurunga and Iranian "Dough" and therefore were adapted to alcohol substrate, had possibility to utilize mannitol. This characteristic is the property of $L$. lactis ssp. cremoris, but not $L$. lactis ssp. That is novel property of new strain of L. lactis ssp. lactis newly established. According to the morphological, cultural, physiological, biochemical properties and gene sequence of $16 \mathrm{~S} r R N A$ these strains were identified as Lactococcus lactis ssp. lactis. 
The special interest was paid to isolates of L. lactis with antifungal activity. It was demonstrated that the bacteriocins they produced varied in antagonistic activity. Some strains, isolated from milk and dairy products of Moscow region, were nisin-synthesizing (inhibit Gram-positive bacteria only). Only nine of the isolated 94 strains expressed a broad spectrum of activity. This property is unique for isolated natural strains of Lactococcus lactis species.

Synthesis of bacteriocin as a protein proceeds concurrently with growth of producer and DNA, RNA synthesis (Diep and Nes, 2002). A study of the growth dynamics of these strains in the fermentation medium with glucose and yeast autolysate demonstrated that their growth was characteristic of mesophylic lactococci. The studies have revealed differences in antimicrobial activity between strains against different groups of microorganisms. Screening of effective antifungal strains from milk and dairy products from different climatic regions and also powerful drinks of mixed lactic acid and alcoholic fermentation: kurunga, kumiss and Iranian "Dough" was perfomed. These strains were identified as $L$. lactis ssp. lactis that have "GRAS" status. The most perspective strains were L. lactis ssp. lactis 194 and K-205, which synthesis antibiotic complex with broad activity spectrum against food-borne pathogens included fungi. Antimicrobial substance A, in concordance with UV-spectrum, molecular mass and spectrum of antimicrobial activity was identified as novel and was absent in J. Berdy database BNPD. Component $\mathrm{C}$ was a peptide with molecular mass 1995 Da smaller then bacteriocin nisin.

Treatment of the raw smoked sausages with cultural broth of these strains of L. lactis ssp. lactis inhibited the spoilage by E. repens. After treatment the sausages had longer shelf-life and integrated products correspond to technological and microbiological indexes. The results of this study indicated that the treatment with these lactococci strains can prevent a contamination of raw smoked sausages with mould.

\section{CONCLUSION}

Screening of effective antifungal strains from milk and dairy products from different climatic regions and also powerful drinks of mixed lactic acid and alcoholic fermentation: kurunga, kumiss and Iranian "Dough" was perfomed. These strains were identified as L. lactis ssp. lactis that have "GRAS" status. The nucleotide sequences of the $16 S$ rRNA genes of novel strains were deposited to the GenBank database under following accession numbers: DQ255952 (strain MGU),
DQ255951 (115), DQ255953 (229), EF114309 (805), EF1143308 (K-205), DQ255954 (194).

The Lactococcus strains enriched the collection of efficient producers of nisin and other bacteriocins. Most effective new bacteriocin-synthesizing strains 194 and K-205 were isolated from raw cow milk and kurunga drink from Buryatia. These strains had high antibiotic activity up to $3600-2700 \mathrm{IU} \mathrm{mL} \mathrm{mL}^{-1}$ respectively, as compared with nisin and up to $2500-1700 \mathrm{IU} \mathrm{mL}^{-1}$ as compared to fungicidal antibiotic nistatin. Antifungal activity among natural strains of $L$. lactis is unique property. This strains produced novel antibiotic complex with broad activity spectrum against foodborne pathogens included fungi that was absent in $\mathrm{J}$. Berdy database BNPD.

Treatment of the raw smoked sausages with cultural broth of these strains of L. lactis ssp. lactis inhibited the spoilage by E. repens. After treatment the sausages had longer shelf-life and products after storage were correspond to technological and microbiological indexes stated by Russian standards.

So, potential applications of cultural broth of these strains in various food fermentations allow to recommend it as potential perspective biopreservatives for preventing fungal spoilage of foodstuffs and edible raw materials.

\section{REFERENCES}

Cutter, C. and G. Siragusa, 1994. Decontamination of beef carcass tissue with nisin using a pilot scale model carcass washer. Food Microbiol., 11: 481-489. DOI: 10.1006/fmic.1994.1054

Drider, D., Y. Fimland, H. McMullen and H. Prevost, 2006. The continuing story of class IIa bacteriocins. Microbiol. Molec. Biol. Revs., 70: 564-582. DOI: 10.1128/MMBR.00016-05

European Parliament and Council, 1997. Regulation (EC) № 258/97 of the European Parliament and of the Council of 27 Jan. 1997 concerning novel foods and novel food ingredients. Official J., 14: 1-7. http://www.biosafety.be/GB/Dir.Eur.GB/FF/258_9 7/258_97.html

Fujita, K., S. Ichimasa, T. Zendo, S. Koga and F. Yoneyama, 2007. Structural analysis and characterization of lacticin $\mathrm{Q}$, a novel bacteriocin belonging to a new family unmodified bacteriocins of gram-positive bacteria. Applied Environ. Microbiol., $\quad 73$ : 2871-2877. DOI: 10.1128/AEM.02286-06

Galvez, A., H. Abriouel, R. Lopez and N. Omar, 2007. Bacteriocin-based strategies for food biopreservation. J. Food Microbiol., 120: 51-70. DOI: 10.1016/j.ijfoodmicro.2007.06.001 
Gost, 2001. 16131-86 Dry sausages. Specifications, Sb. Gostov M.:IPK Izdatelstvo standartov, Russia. http://docs.cntd.ru/document/1200016987/0

Hoelt, J., N.R. Kried, P.H. Sneath, J.T. Staley and S.T. Williams, 1994. Bergey's Mannual of Determinative Bacteriology. 9th Edn., SpringerVerlag, New-York, ISBN: 978-0-683-00603-2

Jack, R., J. Tagg and B. Ray, 1995. Bacteriocins of gram-positive bacteria. Microbiol. Rev., 59: 171-200. PMCID: PMC239359

Jensen, N., C. Melchiorsen, K. Jokumsen and J. Villadsen, 2001. Metabolic behavior of Lactococcus lactis MG1363 in microaerobic continuous cultivation at a low dilution rate. Applied Environ. Microbiol., 67: 2677-2682. DOI: 10.1128/AEM.67.6.26772682.2001

Klich, M.A., U. States, A.R. Service, S.R.R. Center, 2002. Identification of Common Aspergillus Species. Centraalbureau Voor Schimmelcultures. The Netherlands, pp: 116. ISBN: 90-70351-46-3

Lowe, D. and E. Arendt, 2004. Lactic acid bacteria in malting and brewing with their relationships to antifungal activity, mycotoxins and gushing: A review. J. Inst. Brew, 110: 163-180. http://www.scientificsocieties.com/jib/papers/200 4/G-2004-0812-237

Mantovani, H. and J. Russell, 2001. Nisin resistance of Streptococcus bovis. Applied Environ. Microbiol., 67: 808-813. DOI: 10.1128/AEM.67.2.808813.2001

Morgan, S., P. O'Connor, P. Cotter, R. Ross and C. Hill, 2005. Sequential actions of the two component peptides of the lantibiotic lacticin 3147 explain its antimicrobial activity at nanomolar concentrations. Applied Environ. Microbiol., 49: 2606-2611. DOI: 10.1128/AAC.49.7.2606-2611.2005

Nete, B., T. Licht, C. Brogren, B. Jelle and A.H. Johansen, 2006. Effects of Lactococcus lactis on composition of intestinal microbiota: Role of nisin. Applied Environ. Microbiol., 72: 239-244. DOI: 10.1128/AEM.72.1.239-244.2006
Roy, U., V.K. Batish, S. Grover and S. Neelakantan, 1996. Production of antifungal substance by Lactococcus lactis subsp. lactis CHD-28.3. Int. J. Food Microbiol., 32: 27-34. DOI: 10.1016/01681605(96)01101-4

Stoyanova, L., N. Egorov, G. Fyodorova, G. Katrukha and A. Netrusov, 2007. A Comparison of the properties of bacteriocins formed by Lactococcus lactis subsp. lactis strains of diverse origin. Applied Biochim. Mikrobiol., 43: 604-610. DOI: 10.1134/S0003683807060063

Stoyanova, L. and N. Levina, 2006. Components of fermentation medium regulate bacteriocin synthesis by the recombinant strain Lactococcus lactis subsp. lactis F-116. Microbiol, 75: 342-348. DOI: 10.1134/S0026261706030088

Stoyanova, L., T. Sul'timova, S. Botina and A. Netrusov, 2006. Isolation and identification of new nisinproducing Lactococcus lactis subsp. lactis from milk. Applied Biochem. Microbiol., 42: 492-499. DOI: 10.1134/S0003683806050085

Stoyanova, L., T. Sul'timova and A. Netrusov, 2008. Establishment of taxonomic status of new prospective bacteriocin-synthesizing Lactococci strains of various origins. Moscow Univ. Biol. Sci. Bull., 42: 156-162. DOI: 10.3103/S0096392508040044

Yildirim, Z., M. Yildirim and M.G. Johnson, 2004. Mode of action of lactococcin $\mathrm{R}$ produced by Lactococcus lactis R. Nahrung, 48: 145-148. DOI: 10.1002/food.200300404

Zendo, T., M. Fukao, T. Higuchi, J. Nakayama and K. Sonomoto, 2003. Identification of the lantibiotic nisin $\mathrm{Q}$, a new natural nisin variant produced by Lactococcus lactis 61-14 isolated from a river in Japan. Biosci. Biotechnol. Biochem., 67: 1616-1619. DOI: PMC1892864 